\title{
EFFECT OF PREGNANCY ON THE ONSET AND COURSE OF RHEUMATOID ARTHRITIS
}

\author{
BY \\ MARTTI OKA \\ From the Rheumatism Foundation Hospital, Heinola, Finland
}

(RECEIVED FOR PUBLICATION APRIL 2, 1953)

Hench (1938) reported the ameliorating effect of pregnancy upon rheumatoid arthritis, fibrositis, and intermittent hydrarthrosis, and noted the comment of Garrod (1890) that pregnancy acted as a temporary check upon the development of chronic arthritis in some cases. Hench studied the effect of 37 pregnancies in 22 women and found striking relief in 20 of them. The relief of joint symptoms, as a rule, was felt in the early stages of pregnancy, and remission lasted until a few weeks after parturition, when the arthritic symptoms recurred with equal or greater severity. The results achieved by some other scholars seem to point in the same direction. Barcelo Torrent and Alegre Marcet (1951) describe fifteen cases of rheumatoid arthritis, in twelve of which the activity of the disease diminished during pregnancy.

Many theories have been put forward regarding the mechanism of this effect. Hench (1938) suggested that it is the same as or closely related to that responsible for amelioration during jaundice. Touw and Kuipers (1938) assumed that the favourable symptoms during the first 4 or 5 months of pregnancy were caused by the great amount of progestin that was secreted, but experiments with this hormone were not encouraging. The discovery of the ameliorating effect of Compound $E$ brought into logical relationship several previously unrelated facts. The pregnancy effect could be explained either by supplementary $E$ hormone from the foetal adrenal glands (Lansbury, 1949; Kandráč and Flusser, 1950), or by some adrenal cortical stimulant arising from the placenta (perhaps analogous to the chorionic gonadotropins) which causes the well known adrenal cortical hypertrophy of pregnancy (Lansbury, 1949). Kendall (1951) believed that cortisone and the substance causing remission during pregnancy are identical or closely related.

Conjecturing that in pregnancy an unknown substance causes the improvement, and assuming that this substance circulates in the blood, Barsi (1947) treated patients with rheumatoid arthritis by transfusions from pregnant women, and found striking relief of symptoms in most cases.

Very few remarks on this subject can be found in the literature. McKeown (1948) records eight cases in which rheumatic heart disease and damage to the myocardium occurred during pregnancy. Rheumatoid arthritis which began during pregnancy or immediately after delivery has not been regarded as related to the pregnancy.

\section{Material and Methods}

732 female patients suffering from rheumatoid arthritis were treated at the Hospital of the Rheumatism Foundation, Heinola, during the years 1951-52. Those in whom the disease had begun before the age of 15 ( 59 instances altogether) are not included.

The aim of this investigation was to ascertain the interrelation of pregnancy (delivery, section, miscarriage) with the aetiology and symptoms of rheumatoid arthritis.

It was assumed that pregnancy has some effect on the onset of the disease if the first joint symptoms appear during pregnancy, or within 6 months of delivery or 2 months of miscarriage.

The effect of pregnancy was judged by the joint symptoms (pain, swelling, limitation of range of movement) and by changes in general symptoms (general condition, fever, loss of weight).

Most of the necessary information was obtained from the patients' case reports, and if these failed, the patients themselves were questioned, when possible. Questionnaires were sent to 92 patients, of whom more than 90 per cent. duly filled them up. In a few instances the information about the course of the disease during pregnancy or after delivery was not complete, which accounts for the slight disagreement of the figures given in Table III.

\section{Results}

(1) Table I (overleaf) shows the role of pregnancy in the onset of rheumatoid arthritis. In 71 cases of rheumatoid arthritis the disease had begun earlier than 6 months after delivery or section. The number of cases showing the onset of the disease from 6 to 12 months after delivery was considerably lower (21). 
TABLE I

ROLE OF PREGNANCY, DELIVERY, SECTION, AND MISCARRIAGE IN ONSET OF RHEUMATOID ARTHRITIS

\begin{tabular}{|c|c|c|c|}
\hline $\begin{array}{c}\text { Time of Onset } \\
\text { of Rheumatoid } \\
\text { Arthritis }\end{array}$ & $\begin{array}{c}\text { Number } \\
\text { of } \\
\text { Cases }\end{array}$ & $\begin{array}{c}\text { Per cent. } \\
\text { of } \\
\text { Total }\end{array}$ & $\begin{array}{c}\text { Per cent. } \\
\text { of } \\
\text { Mothers }\end{array}$ \\
\hline After delivery (0-6 months) & 70 & $9 \cdot 6$ & $15 \cdot 3$ \\
\hline After section (shortly) $\ldots$ & 1 & $0 \cdot 1$ & $0 \cdot 2$ \\
\hline After miscarriage (0-2 months) .. & 3 & 0.4 & $0 \cdot 7$ \\
\hline During pregnancy & 16 & $2 \cdot 2$ & $3 \cdot 5$ \\
\hline $\begin{array}{c}\text { Total onsets closely related to } \\
\text { pregnancy }\end{array}$ & 90 & $12 \cdot 3$ & $19 \cdot 7$ \\
\hline $\begin{array}{l}\text { Total Patients } \\
\text { Total Pregnancies }\end{array}$ & $\begin{array}{l}732 \\
456\end{array}$ & $62 \cdot 3$ & + \\
\hline
\end{tabular}

A detailed classification of the instances with special reference to the time of onset is found in Fig. 1 (see also Table II).

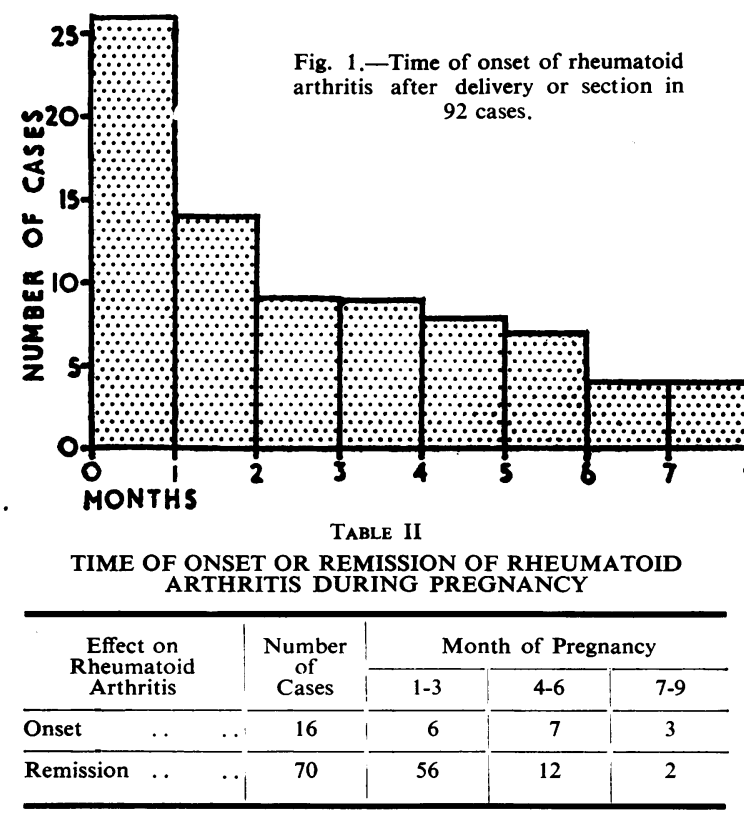

The number of previous pregnancies does not seem to be of importance. In 28 cases the onset of the disease was closely related to the first pregnancy, in 34 cases to the second, in twelve cases to the third, in seven cases to the fourth, and in nine cases to the fifth or later.

The onset of the disease after the delivery of twins was noted in two cases (in the first after 2 weeks, in the second after 1 month).

It seems that whenever the disease has set in within one month of delivery its onset is more commonly acute or subacute (Fig. 2).
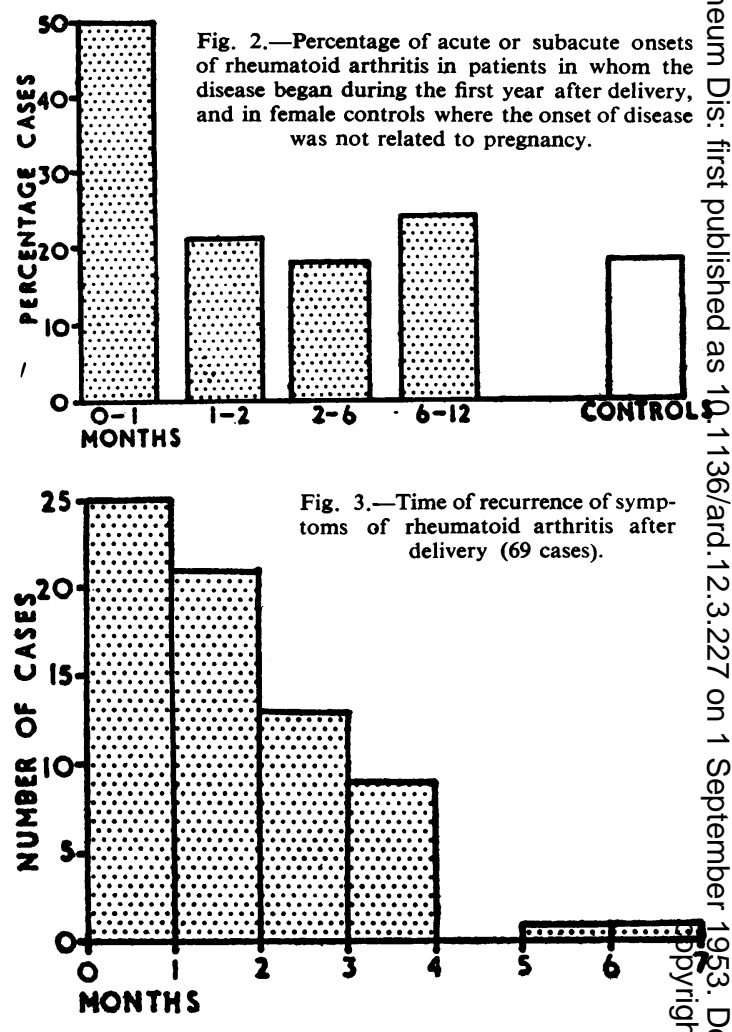

(2) Table III (opposite shows the development of rheumatoid arthritis duro ing pregnancy and afte delivery, section, or mis carriage. The time of remission of joint symptoms during pregnancy is shown in Table II, and that of recurrence after delivery in Fig. 3.

In 59 out of 101 females, and in 77 out of $13 \%$ deliveries or sections, the joint symptoms grews worse than they were before pregnancy, and in the majority the disease spread to healthy, hitherto $\frac{3}{3}$. unaffected joints. Aggravation of joint symptom\& and elevated temperature were frequent, the patient having to remain in bed for several monthso

The effect of the patient's previous pregnancies on disease symptoms were, in general, very similaro

\section{Conclusions}

(1) The onset of rheumatoid arthritis during preg nancy or immediately after it is so common that ine certain circumstances pregnancy can be regarded as an aetiological factor.

(2) Remission during pregnancy and relapse anẹ̣ even aggravation after delivery were general. 
TABLE III

EFFECT OF PREGNANCY, MISCARRIAGE, DELIVERY, AND SECTION ON COURSE OF RHEUMATOID ARTHRITIS

\begin{tabular}{|c|c|c|c|c|c|c|c|c|c|c|c|}
\hline & & & & & & & & ect on $\mathbf{R}$ & hatoid Arthrit & & \\
\hline Chil & d-be & & & of & of & $\mathrm{Fa}$ & urable & & ourable & & \\
\hline & & & & & & Patients & Pregnancies & Patients & Pregnancies & Patients & Pregnancies \\
\hline Pregnancy & . & . & . & 93 & 114 & 70 & 88 & 12 & 15 & 11 & 11 \\
\hline Miscarriage & $\ldots$ & . & $\ldots$ & 15 & 17 & 7 & 7 & 4 & 6 & 4 & 4 \\
\hline Delivery & . & $\ldots$ & $\ldots$ & 100 & 131 & 4 & 5 & 81 & 109 & 15 & 17 \\
\hline Section & $\ldots$ & $\ldots$ & $\ldots$ & 1 & 1 & 0 & 0 & 1 & 1 & 0 & 0 \\
\hline
\end{tabular}

\section{Summary}

The effect of pregnancy on the onset and course of rheumatoid arthritis has been investigated in 732 female patients who had contracted the disease after the age of 15 , and the following points noted:

(1) The first symptoms of rheumatoid arthritis appeared during pregnancy in sixteen cases, within 6 months after delivery in seventy cases, and after section in one, and within 2 months after miscarriage in three cases. The onset of the disease was closely related to pregnancy in ninety cases $(12 \cdot 3$ per cent. of all cases; $19 \cdot 7$ per cent. of all mothers).

An acute or subacute onset immediately after delivery was noticed in 50 per cent. of the 26 patients who contracted the disease within a month of delivery. If the onset of the disease had occurred during pregnancy or at a later stage after delivery, no great difference could be observed when compared with 621 controls, in whom the corresponding percentage was $18 \cdot 8$.

(2) Relief of symptoms was found in seventy of 93 patients, and in 88 of 114 pregnancies. Recurrence of the symptoms-generally within 4 months-was noticed in 82 of 101 patients, and in 110 of 132 deliveries or sections. There was an aggravation of joint symptoms in 59 of 101 patients $(58 \cdot 4$ per cent.), and in 77 of 132 deliveries or sections ( $58 \cdot 3$ per cent.). The course of the disease after miscarriage varied from case to case.

\section{REFERENCES}

Barcelo Torrent, P., and Alegre Marcet, C. (1951). Rev. ispañ. reumat., 4, 2, 96

Barsi, I. (1947). Brit. med. J., 2, 252.

Garrod, A. E. (1890). "Treatise on Rheumatism and Rheumatoid Arthritis" quoted in "Allbutt's System of Medicine"' (1901), vol. 3 , p. 102 .

Hench, P. S. (1938). Proc. Mayo Clin., 13, 161.

Kandráč, M., and Flusser, J. (1950). Ćarop. lék. česk., 89, 889.

Kendall, E. C. (1951). Lancet, 2, 586.

Lansbury, J. (1949). In “Comroe's Arthritis”, p. 490, 4th ed., ed. J. L. Hollander. Kimpton, London.

McKeown, F. (1948). J. Obstet. Gynaec., 55, 50.

Touw, J. F., and Kuipers, R. K. W. (1938). Acta med. scand., 96, 501.

\section{Effet de la grossesse sur l'arthrite rhumatismale}

RÉSUMÉ

On étudia l'effet de la grossesse sur le début et l'évolution de l'arthrite rhumatismale chez 732 femmes ayant contracté cette maladie après l'âge de 15 ans.

(1) Les premiers symptômes de l'arthrite rhumatismale apparurent au cours de la grossesse dans seize cas, au cours de premiers six mois après l'accouchement dans 70 cas, après une ćesarienne dans un cas et au cours des 2 mois après un avortement dans trois cas. Le début de la maladie fut étroitement lié à la grossesse dans 90 cas $(12,3$ pour cent de tous les cas, 19.7 pour cent de toutes les mères).

Un début aigu ou subaigu immédiatement après l'accouchement fut observé dans 50 pour cent des 26 femmes ayant contracté la maladie au cours du premier mois après l'accouchement. Si la maladie avait commencé pendant la grossesse ou plus tard après l'accouchement, on n'aurait pas trouvé de grande différence entre ce groupe et un groupe de 621 témoins chez qui le pourcentage correspondant fut de 18,8 pour cent.

(2) On nota une amélioration symptomatique chez 70 sur 93 malades et chez 88 sur 114 grossesses. Le retour des symptômes-habituellement en dedans de 4 moisfut observé chez 82 sur 101 malades et dans 110 sur 132 accouchements ou césariennes. Il y eut une aggravation des symptômes articulaires chez 59 sur 101 malades $(58,4$ pour cent) et dans 77 sur 132 accouchements ou césariennes $(58,3$ pour cent). L'évolution de la maladie après un avortement varia selon les cas.

\section{El efecto de la preñez sobre la artritis reumatoide} SUMARIO

Se estudió el efecto de la preñez sobre el comienzo y el curso de la artritis reumatoide en 732 mujeres habiendo contraido esta enfermedad después de la edad de 15 años.

(1) Los primeros síntomas de la artritis reumatoide aparecieron en el curso de la preñez en 16 casos, en el curso de los primeros seis meses después del parto en 70 cases, después de una cesárea en un caso y en el curso de los dos meses después de un aborto en tres casos. El principio de la enfermedad tuvo una relación estrecha con la preñez en 90 casos (12,3 por ciento de todos los casos, 19,7 por ciento de todas le madres).

Se observó un principio agudo o subagudo inmediatamente después del parto en al 50 por ciento de las mujeres habiendo contraido la enfermedad en el curso del primer mes que siguió el parto. Si la enfermedad hubiera empezado durante la preñez o después del período considerado aquí, poca diferencia habría entre este grupo y un grupo de 621 testigos, en que el percentage correspondiente fué de 18 por ciento.

(2) Se notó un alivio sintomático en 70 de las 93 enfermas y en 80 de los 114 embarazos. Los síntomas recurrierongeneralmente dentro de 4 meses - en 82 de los 101 enfermas y en 110 de los 132 partos o cesáreas. Los síntomas articulares empeoraron en 59 de las 101 enfermas $(58,4$ por ciento) y en los 77 de los 132 partos o cesáreas (58,3 por ciento). El curso de la enfermedad después de un aborto fué variable según el caso. 